\title{
Aydın İl Merkezindeki 15-49 Yaş Grubu Kadınlarda Akraba Evliliği Sıklığı ve Etkileyen Faktörler*
}

\author{
The Incidence of Consanguineous Marriages and Affecting Factors in \\ Women Aged 15-49 Years in Aydin, Turkey
}

\author{
Şennur Rabia ŞEN**, Hilmiye AKSU***
}

İletişim: Hilmiye AKSU Adres/Adress: Adnan Menderes Üniversitesi Aydın Sağlık Yüksekokulu Tel: 02562138866 Faks: 02562124219

E mail: hilmiyeaksu@yahoo.com

\begin{abstract}
$\ddot{O} Z$
Amaç: Bu çalışma, Aydın il merkezinde yaşayan 15-49 yaş grubu evli kadınlar arasında akraba evliliği sıklığı ve etkileyen faktörleri incelemek amacıyla yapıldl.

Yöntem: Kesitsel tipteki bu araştırmada $15-49$ yaş grubu 310 evli kadın ile çalışıldı. Veri toplama, kadınlara kendi evlerinde yüz yüze görüşme yöntemi ile 53 soruluk anket formu uygulanarak gerçekleştirildi. Veriler 15 Kasım 2008-15 Ocak 2009 tarihleri arasında toplandl. Istatistiksel değerlendirmede ki-kare testi kullanıld. Verilerin tanımlanmasinda ortalama sayı ve yüzde kullanıldı. Değerlendirmelerde $p<0.05$ düzeyi anlamlı olarak kabul edildi.

Bulgular: Araş̧tırmaya katılan 15-49 yaş evli kadınlar arasinda akraba evliliği yapanlar \%23,9 (74 kişi) olarak belirlendi. Bunların\%45,9'u birinci derece kuzen evliliği, \%24,3'üikinci derece kuzen evliliği ve\%29,8'si uzak akraba evliliği yapmuşlardır. Kadınların eğitim durumunun düşük olması, gelir getiren bir işte çalışmaması, yaşadığı yerin kırsal yerleşim yeri olması, aile tipinin geniş aile olması ve ilk evlilik yaşının düşük olması ile akraba evliliği tercih etme durumları artmaktadır.

Sonuç: Bu çalışmanın sonucunda akraba evliliği oranın yüksek olduğu ve eğitim durumu, gelir getiren bir işte çalışması, yaşadığı yer, aile tipi gibi bazı sosyo-demografik özelliklerin akraba evliliği ile ilişkisi olduğu söylenebilir Akraba evliliklerini azaltmak için kadının eğitiminin sağlanması ve ekonomik özgürlüklerinin sağlanması önerilebilir.
\end{abstract}

Anahtar Kelimeler: Kadın să̆llğı, akraba evliliği, görülme sıklı̆̆l.

\section{ABSTRACT}

Aim: The aim of this study was to determine the incidence of consanguineous marriages and affecting factors in women aged 15-49 years in Aydin, Turkey.

Method: This is a cross-sectional study including 310 married women aged 15-49 years. Data were collected with a questionnaire composed of 53 questions at face to face interviews at home visits between 15 October 2008 and 15 January 2009. Obtained data were analyzed with numbers, percentages, mean and Chi-square test. $p<0.05$ was considered significant.

Results: All of the women included in the study, 23.9\% (n=74) had consanguineous marriage. Out of these women, $45.9 \%$ were married to their first degree cousins, $24.3 \%$ were married to their second degree cousins and $29.8 \%$ were married to their remote relatives. Low education levels, not having a job providing income, having an extended family, living in the rural areas and young age at the first marriage increased the tendency for consanguineous marriages.

Conclusion: The study showed a high rate of consanguineous marriages, and a relation between consanguineous marriages and education, income, family type, place of residence and age at first marriage. It can be recommended that women should be provided with economic freedom and education so that the rate of consanguineous marriages can be reduced.

Key Words: Women's health, consanguineous marriages, incidence.

\footnotetext{
"Adnan Menderes Üniversitesi Sağllk Bilimleri Enstitüsü Yüksek Lisans Tezi 2011; 10. Uludă̆ Jinekoloji ve Obstetri Klş Kongresi’nde poster bildiri olarak sunulmuştur (02-06 Mart 2011, Bursa), ${ }^{* *}$ Uzman Hemşire Akdeniz Üniversitesi Hastanesi, ${ }^{* * *}$ Doç. Dr. Adnan Menderes Üniversitesi Aydın Sağllk Yüksekokulu
}

Yazının gönderilme tarihi: 03.04.2014

Yazının basım için kabul tarihi: 29.05.2015 


\section{GíRiş}

Akraba evliliği, eşler arasında kan bağı bulunma yani aynı atadan gelme durumudur. Akraba evliliği genetik hastalıkların epidemiyolojisini etkileyen düşük, ölü doğum, beş yaş altı çocuk ölümü, konjenital anomali gibi olumsuz gebelik sonuçlarına yol açan ve tahminlere göre dünya toplumunun \%20'si tarafindan tercih edilen bir durumdur. Ülkemizde ise 2006 Türkiye İstatistik Kurumu (TÜİK)'nun Aile Yapısı incelemesi sonuçlarına göre eşiyle akraba olan kadınların oranı \%20,9 iken 2012 yllında bu oran \%23,3 olarak bildirilmiştir (TÜİK 2012). Bu sıklık yöreler arasında ciddi farkl1lıklar göstermektedir ve ülkenin batısından doğusuna doğru gidildikçe artmaktadır (Özvarış 2001; Tavukçu ve İrgil 2008; Tekbaş, Oğur ve Uçar 2005; Uskun 2001). Türkiye'de bölgelere göre bakıldığında en yüksek oran Güneydoğu ve Doğu Anadolu'da sirasıyla \%40,4 ve \%30,7, en düşük oran ise batı Marmara ve Ege'de sirasıly \% 4,8 ve $\% 17,4$ olarak rapor edilmiştir (TUIK 2006).

Kan yakını akrabalar genel toplumda görülen ortak gen yüzdesinin haricinde ayrıca akraba oldukları için, akrabalık derecesine göre daha fazla ortak (aynı) genlere sahiptirler (Genç ve Erdemir 1997; Özvarış, Koçoğlu ve Akın 2002; Tekbaş ve ark. 2005; Uskun 2001). Bu nedenlerle akraba evliliklerinin çocuklarında her iki ebeveynden gelebilecek ayn allelin bir gen merkezinde toplanma riski genel toplumdakine göre daha yüksektir. Dolayısıyla hastalık oluşturma riski de genel topluma göre daha yüksektir (Genç ve Erdemir 1997). Yani akraba evlilikleri heterozigot ya da taşıyıcı dediğimiz kişileri yan yana getirerek ilgili hastalık ya da nitelik için homozigotların doğma şansını artırmaktadır (Özcan 2008).

Akraba evliliği yapan popülasyonda özürlü çocuk doğma riski diğer popülasyona göre iki kat artarak \%8-9 olmaktadır (Özcan 2008; Özvarış ve ark. 2002; Tekbaş ve ark. 2005; Uskun 2001). Yapılan çalışmalarda akraba evliliklerinin düşük sosyoekonomik durum, düşük eğitim düzeyi ve kırsal kesimde yaşamayla ilişkili olduğu bulunmuştur (Kutlubay 2007; Sayg1- l1 1998; Șenel, Şahin, Süslü ve Güntürk 2009; Tabak 2008; Tavukçu ve İrgil 2008; Zencir 2005). Genel toplumda eğitimin artması ve sosyoekonomik koşulların düzelmesi ile akraba evliliği sıklığı giderek azalmasına karşın hala yaygın ve kapsamlı çözüm üretmeyi gerektiren bir sorundur. Evlenmeyi planlayan bireylere akraba evliliklerinden kaçınılması gerekliliği vurgulanmalı, akraba evliliği yapmış olan bireylerin genetik danışma almak için bir genetik uzmanı ile görüşmeleri sağlanmalı, bu gebelikler ve doğan bebekler yakından izlenmelidir. Ayrıca toplumda sık görülen otozomal resesif hastalıkların taşıyıcıları belirlenmeli ve erken teşhis için uygulanan tarama programları yaygınlaştırılmalıdır. Bu hizmetlerin sunumunda hemşireler aktif rol alabilmektedir. Aydın il merkezinde akraba evliliği görülme sıklığının belirlenmesi ile sağlık eğitim hizmetlerinin planlanması ve sunumu kolaylaşabilir. Bu nedenle bu çalışmada Aydın il merkezinde 15-49 yaş grubu evli kadınlar arasında akraba evliliği sıklığını ve akraba evliliğini etkileyen faktörleri incelemek amaçlanmıştır.

\section{YÖNTEM}

$\mathrm{Bu}$ çalışma tanımlayıcı bir araştırmadır. Araştırmanın evrenini Aydın il merkezindeki 1,2,3,4,5,6,7,8 ve 9 No'lu sağlık ocakları bölgelerinde kentsel alanda yaşayan 15-49 yaş grubundaki 33.993 evli kadın oluşturmuştur. Araştırmaya katılan kadınlar dokuz sağlık ocağ 1 bölgesinden tabakalı örneklem yöntemiyle rasgele seçilmiştir. Araştırmaya dahil olma kriterleri 1549 yaş grubunda olma, evli olma ve araştırmaya katılmayı kabul etmektir.

Örnekleme alınan birey sayısı evreni bilinen örnekleme yöntemi ile 254 olarak belirlenmiştir. Kadınlara ulaşamama ve araştırmaya katılmayı reddetme olasılığı nedeniyle \%30 yedek alındığında, toplam örneklem büyüklüğü 330 olarak tespit edilmiştir. Aydın il merkezindeki $1,2,3,4,5,6,7,8$ ve 9 No'lu sağlı ocakları bölgelerinde sirasıyla 48, 48, 36, 26, 34, 6, 38, 32, 62 kadınla yürütülmüşsür. Ancak 20 kadından 15'ine çalışma hayatı sebebiyle (tarımsal etkinliklerin başladığı dönem olduğu için), 2 kadın çalışmaya katılmayı 
kabul etmediği için ve 3 kadına da şehir dışında oldukları için ulaşılamamıştır. Ulaşılamayan kadınlar $3 \mathrm{kez}$ evlerinde ziyaret edilmiştir ve araştırma 310 evli kadın ile tamamlanmıştır.

Veriler 53 soruluk anket formu ile toplanmıştır. Anket formu kadınların ve eşlerinin tanıtıcı özellikleri, kadınların doğurganlık özellikleri, akraba evliliği ve akrabalık dereceleri, akraba evliliği ile ilgili tutumlarını içeren sorulardan oluşmaktadır. Anket formunun anlaş1lırlık ve uygulanabilirliğini test etmek için 10 kadın ile ön uygulama yapılmıştır.

Örnekleme alınan kadınların adresleri sağlık ocağı otomasyon bilgi bankasından elde edilmiştir. Adresleri belirlenen kadınlar evlerinde ziyaret edilmiş, araştırma hakkında bilgi verildikten sonra araştırmaya katılmayı kabul edenlerin yazılı onamları alınmıştır. Sonra araştırmacı tarafından yüz yüze görüşme tekniği kullanılarak anket formu doldurulmuştur. Anket formunun doldurulması yaklaşık 20-30 dakika sürmüştür. Veri toplama sonrasında akraba evliliği ile ilgili bilgi eksikliği olan kadınlara danışmanlık verilmiş ve akraba evliliği yapan kadınlar genetik polikliniğine yönlendirilmiştir.

Veriler bilgisayar ortamında SPSS for Windows 13.0 (Statistical Package for Social Sciences,) istatistiksel paket programı ile analiz edilmiştir. Verilerin analizinde tanımlayıcı istatistikler ve Ki-kare $\left(\chi^{2}\right)$ testi kullanılmıştır. Değerlendirmelerde $\mathrm{p}<0.05$ düzeyi anlamlı olarak kabul edilmiştir. Akrabalık derecesi sınıflanırken, kardeş çocuklarının evliliği birinci derece, kardeş torunlarının evliliği ikinci derece, daha uzak akrabaların evliliği üçüncü derece olarak değerlendirilmiştir.

Araştırmanın yapılabilmesi için Aydın Valiliği İl Sağlık Müdürlüğü'nden yazılı izin alınmıştır. Araştırma protokolüne Adnan Menderes Üniversitesi Tıp Fakültesi Etik Kurulu tarafindan uygunluk onayı verilmiştir.

\section{BULGULAR}

Katılımcıların yaş dağılımına bakıldığında kadınların yaş ortalaması $31,57 \pm 9,00$, eşlerinin yaş ortalamas1 ise $36,15 \pm 9,62$ olarak bulunmuştur. Kadınların \%53,5'inin eşlerinin ise \%49'unun ilkokul mezunu olduğu saptandı. Kadınların \%78,7'sinin ev hanımı olduğu, eşlerinin \%46,8'sinin serbest meslek ile uğraşt1$\breve{g} 1$ belirlendi. Araştırmaya katılan kadınların ilk evlilik yaşı ortalaması 19,98+3,58 iken erkeklerde ilk evlilik yaşı ortalaması $24,61 \pm 4,28$ olarak bulundu (Tablo 1).

Kadınların\%46,1'i en uzun süre şehir merkezinde yaşadığını bildirdi. Kadınların büyük çoğunluğu çekirdek ailede yaşadığını $(\% 81,9)$ ve sosyal güvencelerinin olduğunu $(\% 92,9)$ ve $\% 53,5$ 'i gelirlerinin giderlerine eşit olduğunu belirtmişlerdir.

Araştırmaya katılan 15-49 yaş evli kadınlar arasında akraba evliliği yapanlar oranı \%23,9 ( $\mathrm{s}=74)$ olarak belirlendi. Bunların \%45,9'u birinci derece kuzen evliliği, \%24,3'ü ikinci derece kuzen evliliği ve \%29,8'si uzak akraba evliliği yapmışlardır. Akraba evliliği yapan kadınlardan şimdiye kadar genetik danışma hizmeti alıp almadıkları sorulduğunda \%86,5'i danışmanlık hizmeti almadıklarını bildirmiştir.

Katılımcıların eğitim düzeyi ile akraba evliliği dağ1lımına bakıldığında hem kadının hem erkeğin eğitim düzeyi (Tablo 1) arttıkça akraba evliliğini tercih etme durumu azalmaktadır. Kadınların eğitim düzeyine göre akraba evliliği yapma durumları arasındaki fark karşılaştırıldığında bulgular istatistiksel açıdan anlam11 bulunmuştur $(p=0,000)$. Erkeklerin eğitim düzeyine göre akraba evliliği yapma durumları arasında da anlamlı bir fark saptanmıştır $(\mathrm{p}=0,044)$.

Akraba evliliği yapmayan kadınların \%24,6's1 gelir getiren bir işte çalışmakta iken, bu oran akraba evliliği yapanlarda \%10,8'dir (Tablo 1). Kadınların çalışma durumuna göre akraba evliliği yapma durumu karş1laştırıldığında aralarındaki fark anlamlı bulunmuştur $(p=0,012)$. Araştırmaya alınan erkeklerin çalışma durumlarının ile akraba evliliği durumları arasında ise anlamlı bir ilişki bulunmamıştır $(\mathrm{p}=0,698)$.

Kadınların hayatları boyunca en uzun süre yaşadıkları yerleşim yerinin akraba evliliği ile aralarındaki ilişki incelendiğinde anlamlı bir fark saptanmıştır. Akraba evliliğini tercih etme durumu köy ve kasaba/ilçede ya- 
Aydın İl Merkezindeki 15-49 Yaş Grubu Kadınlarda Akraba Evliliği Siklı̆̆ı ve Etkileyen Faktörler

Tablo 1. Kadınların ve Eşlerinin Sosyo-Demografik Özelliklerine Göre Akraba Evliliği Yapma Durumlarının Dağılımı (N=310)

\begin{tabular}{|c|c|c|c|c|c|c|c|c|}
\hline \multirow{2}{*}{ Kadınların Eğitim Durumu } & \multicolumn{2}{|c|}{ Akrabalık var } & \multicolumn{2}{|c|}{ Akrabalık yok } & \multicolumn{2}{|c|}{ Toplam } & Sd & $\chi^{2} / \mathbf{p}$ \\
\hline & $\mathbf{S}$ & $\%$ & $\mathbf{S}$ & $\%$ & $\mathbf{S}$ & $\%$ & \multirow{3}{*}{1} & \multirow{3}{*}{$X^{2}=15,763 / 0,000$} \\
\hline İlkokul mezunu ve altı & 62 & 83,8 & 138 & 58,5 & 200 & 64,5 & & \\
\hline Ortaokul mezunu ve üstü & 12 & 16,2 & 98 & 41,5 & 110 & 35,5 & & \\
\hline \multicolumn{9}{|l|}{ Eşlerin Eğitim Durumu } \\
\hline İlkokul mezunu ve altı & 46 & 62,2 & 115 & 48,7 & 161 & 51,9 & \multirow{2}{*}{1} & \multirow{2}{*}{$\begin{array}{c}\mathrm{X}^{2} 4,073 \\
/ 0,044\end{array}$} \\
\hline Ortaokul mezunu ve üstü & 28 & 37,8 & 121 & 51,3 & 149 & 48,1 & & \\
\hline \multicolumn{9}{|l|}{ Kadınların Çalışma durumu } \\
\hline Çalışıyor & 8 & 10,8 & 58 & 24,6 & 66 & 21,3 & \multirow{2}{*}{1} & \multirow{2}{*}{$\mathrm{X}^{2}=6,370 / 0,012$} \\
\hline Çalışmiyor & 66 & 89,2 & 178 & 75,4 & 244 & 78,7 & & \\
\hline \multicolumn{9}{|l|}{ Eşlerin Çalışma durumu } \\
\hline Çalışıyor & 68 & 91,9 & 220 & 93,2 & 288 & 92,9 & \multirow{2}{*}{1} & \multirow{2}{*}{$\begin{array}{c}\mathrm{X}^{2}=0,151 \\
/ 0,698\end{array}$} \\
\hline Çalışmiyor & 6 & 8,1 & 16 & 6,8 & 22 & 7,1 & & \\
\hline \multicolumn{9}{|c|}{ Kadınların en uzun süre yaşadığı yer } \\
\hline Köy & 32 & 43,2 & 55 & 23,3 & 87 & 28,1 & \multirow{3}{*}{2} & \multirow{3}{*}{$\begin{array}{c}\mathrm{X}^{2}=11,215 \\
/ 0,004\end{array}$} \\
\hline Kasaba/ilçe & 14 & 18,9 & 66 & 28,0 & 80 & 25,8 & & \\
\hline Şehir merkezi & 28 & 37,8 & 115 & 48,7 & 143 & 46,1 & & \\
\hline \multicolumn{9}{|l|}{ Aile tipi } \\
\hline Çekirdek aile & 52 & 70,3 & 202 & 85,6 & 254 & 81,9 & \multirow[b]{2}{*}{1} & \multirow{2}{*}{$\begin{array}{c}X^{2}=8,937 \\
/ 0,003\end{array}$} \\
\hline Geniş aile & 22 & 29,7 & 34 & 14,4 & 56 & 18,1 & & \\
\hline \multicolumn{9}{|l|}{ Algılanan gelir düzeyi } \\
\hline Gelir giderden fazla & 18 & 24,3 & 47 & 19,9 & 65 & 21,0 & \multirow{3}{*}{2} & \multirow{3}{*}{$\begin{array}{c}X^{2}=1,049 \\
/ 0,592\end{array}$} \\
\hline Gelir gidere eşit & 36 & 48,6 & 130 & 55,1 & 166 & 53,5 & & \\
\hline Gelir giderden az & 20 & 27,1 & 59 & 25,0 & 79 & 25,5 & & \\
\hline \multicolumn{9}{|l|}{ Sosyal güvence } \\
\hline Var & 70 & 94,6 & 218 & 92,4 & 288 & 92,9 & \multirow[b]{2}{*}{1} & \multirow{2}{*}{$\begin{array}{c}X^{2}=0,422 \\
/ 0,516\end{array}$} \\
\hline Yok & 4 & 5,4 & 18 & 7,6 & 22 & 7,1 & & \\
\hline Kadınların ilk evlenme yaşı & & & & & & & & \\
\hline 18 yaş ve altı & 41 & 55,4 & 82 & 34,7 & 123 & 39,7 & & $X^{2}=10,050$ \\
\hline 19-29 yaş & 32 & 43,2 & 149 & 63,1 & 181 & 58,4 & & $/ 0,007$ \\
\hline 30 yaş ve üstü & 1 & 1,4 & 5 & 2,2 & 6 & 1,9 & 2 & \\
\hline Eşlerin ilk evlenme yaşı & & & & & & & & \\
\hline 18 yaş ve altı & 9 & 12,1 & 17 & 7,2 & 26 & 8,4 & & $X^{2}=4,868$ \\
\hline 19-29 yaş & 62 & 83,8 & 192 & 81,4 & 254 & 81,9 & & $/ 0,088$ \\
\hline 30 yaş ve üstü & 3 & 4,1 & 27 & 11,4 & 30 & 9,7 & 2 & \\
\hline
\end{tabular}

şayanlar arasında daha fazla görülmektedir $(\mathrm{p}=0,004)$. Tablo1'de görüldüğü gibi geniş ailede yaşayanlar arasında çekirdek ailede yaşayanlara göre akraba evliliği daha fazla görülmüştür ve akraba evliliği ile aile tipi arasında anlamlı bir ilişki bulunmuştur. Geniş ailede yaşayanların akraba evliliğini tercih edenlerin oranı daha yüksektir $(\mathrm{p}=0,003)$. Kadınların gelir durumlarına göre akraba evliliği yapma durumları arasındaki fark anlamsız bulunmuştur $(\mathrm{p}=0,592)$. Sosyal güvencesi olan ve olmayanların akraba evliliği yapma durumları arasında anlamlı bir fark saptanmamış$\operatorname{tir}(\mathrm{p}=0,516)$. 
Araştırma grubundaki kadınların ortalama ilk evlilik yaş1 19,98+3,58 iken erkeklerde ilk evlilik yaşı ortalaması 24,61 $\pm 4,28$ olarak bulunmuştur. Kadınların ilk evlenme yaşlarına göre akraba evliliği yapma durumlarına bakıldığında aralarında istatistiksel olarak anlamlı fark bulunmuştur ( $p=0,007)$. İlk evlilik yaşı ilerledikçe akraba evliliğini tercih etme oranı azalmaktadır. Erkeklerin ilk evlilik yaşı ve akraba evliliği durumu karşılaştırıldığında aralarındaki fark anlamsızdır $(\mathrm{p}=0,088$, Tablo1).

$\mathrm{Bu}$ araştırmaya katılan kadınların gebelik sayısı 2.79, canlı doğum sayısı 2.08, ölü doğum yapma sayıs1 0.07 , yaşayan çocuk sayısı $2.041 \pm 1.27$, düşük sayıs1 0.34 , kürtaj sayısı 0.27 ve olarak saptanmıştır. Kadınlarda infertilite oran $1 \% 7.7$ olarak bulunmuştur. Araştırmanın önemli bir konusu olan gebelik sonuçları ve akraba evliliği arasındaki ilişki irdelendiğinde; toplam gebelik sayıları akraba evliliği yapan grupta daha fazla olsa da aradaki fark anlamlı bulunmamıştır $\left(\mathrm{X}^{2}=2.578\right.$, $\mathrm{p}>0.05)$. Canlı doğum sayısı akraba evliliği yapan grupta yapmayan gruptaki kadınların canlı doğum sayısından fazla bulunmuş ve aradaki fark istatistiki olarak anlamlı saptanmıştır $\left(X^{2}=19.609 \mathrm{p}<0.05\right)$. Ölü doğum sayıları ve akraba evliliği arasında anlamlılık saptanmazken $\left(\mathrm{X}^{2}=0.762 \mathrm{p}>0.05\right)$, ilk beş y1l içinde ölen çocuk sayıları ve akraba evliliği arasında anlamlı bir fark saptanmıştır $\left(\mathrm{X}^{2}=8.032 \mathrm{p}<0.05\right)$. Kadınların yaşayan çocuk sayıları akraba evliliği yapanlarda anlamlı olarak daha yüksektir $\left(\mathrm{X}^{2}=11.317 \mathrm{p}<0.05\right)$.

Araștırma grubundaki akraba evliliği yapan 74 kişinin akraba evliliği seçme nedenleri Tablo 2'de belirtilmiştir. Bu nedenler arasında en çok \% 44,5 ile ailelerin karar vermesi/görücü usulü, \%37,9 ile birbirlerini sev-
Tablo 2. Akraba Evliliği Yapan Kadınların Akraba Evliliğini Seçme Nedenlerine Göre Dağılımı

\begin{tabular}{|l|c|c|}
\hline Akraba Evliliğini Seçme Nedenleri & S & $\mathbf{\%}$ \\
\hline Aileler karar verdi+görücü usulü ile & 33 & 44,5 \\
\hline Birbirimizi sevdik & 28 & 37,9 \\
\hline Geleneksel+mecburi & 8 & 10,9 \\
\hline Görücü usulü+sevdik & 2 & 2,7 \\
\hline Önceden tanıdık olduğu için & 2 & 2,7 \\
\hline Sevdik+geleneksel & 1 & 1,3 \\
\hline Toplam & 74 & 100 \\
\hline
\end{tabular}

dikleri için tercih ettikleri ve $\% 10,9$ ile geleneksel nedenler gösterilmiştir.

Tablo 3'de akraba evliliği yapan ve yapmayan gruplara "akraba evliliğinin doğacak olan çocuklara sizce bir sakıncası var mıdır?" sorusu yöneltilerek her iki grubun bu konudaki fikri alınmış ve aralarındaki ilişki incelenmiştir. Akraba evliliğinin doğacak çocukların sağlığı açısından sakıncalı olup olmadığının akraba evliliği yapan ve yapmayan kişilerin bakış açıları arasındaki farklılık istatistiksel olarak anlamlı bulunmuştur. Akraba evliliği yapan kadınlar arasında akraba evliliği yapmanın, doğacak çocukların sağlı̆̆ üzerinde etkisinin olmayacağı görüşü daha yaygındır $(\mathrm{p}=0,000)$.

Akraba evliliği olan kadınların çocuklarındaki doğumsal defektlerin böbrek anomalisi $(\mathrm{n}=1)$, sağırlık $(\mathrm{n}=1)$, kalp defekti $(n=2)$, yarık damak-dudak $(n=1)$ olduğu; akraba evliliği bulunmayan kadınların çocuklarındakinin ise böbrek anomalisi $(n=1)$, kol-bacak deformitesi $(n=1)$, beyin ödemi ( $n=1)$, şaş1lık $(n=1)$, kalp defekti $(n=2)$ ve skolyoz ( $\mathrm{n}=1)$ olduğu belirlenmiştir. Doğumsal defektlerin varlığının akraba evliliği ile karşılaştırılmasında aradaki fark istatistiksel olarak anlamsızdır. $(\mathrm{p}=0.313)$.

Tablo 3. Kadınların Akraba Evliliğinin Çocuklar Üzerindeki Sakıncalarına Ait Görüşleri ile Akraba Evliliği Arasındaki İlişkiye Göre Dağılımı

\begin{tabular}{|c|c|c|c|c|c|c|c|c|}
\hline \multirow{2}{*}{ Akraba Evliliğinin Sakıncaları } & \multicolumn{2}{|c|}{ Akraba evliliği var } & \multicolumn{2}{|c|}{ Akraba evliliği yok } & \multicolumn{2}{|c|}{ Toplam } & Sd & Ki-kare/p değeri \\
\hline & $\mathbf{S}$ & $\%$ & $\mathbf{s}$ & $\%$ & $\mathbf{s}$ & $\%$ & \multirow{4}{*}{2} & \multirow{4}{*}{$\begin{aligned} X^{2} & =63,634 \\
p & =0,000\end{aligned}$} \\
\hline Var & 38 & 51,4 & 203 & 86,0 & 241 & 77,7 & & \\
\hline Yok & 30 & 40,5 & 11 & 4,7 & 41 & 13,3 & & \\
\hline Bilmiyorum & 6 & 8,1 & 22 & 9,3 & 28 & 9,0 & & \\
\hline
\end{tabular}


Katılımcı kadınların akraba evliliğginin sakıncalı olduğunu nereden ya da kimden öğrendikleri incelendiğinde, \%30'unun medya+çevre ve \%25,8'inin çevreden ve sadece \%3,7'sinin sağlı personelinden öğrendikleri bulunmuştur (Tablo 4).

Tablo 4. Kadınların Akraba Evliliğinin Sakıncalı Olduğunu Öğrendikleri Bilgi Kaynaklarına Göre Dağılımı

\begin{tabular}{|l|c|c|}
\hline $\begin{array}{l}\text { Akraba Evliliğinin Sakıncalarının } \\
\text { Öğrenildiği Kaynaklar }\end{array}$ & S & \% \\
\hline Medya+Çevre & 73 & 30,0 \\
\hline Çevre (komşu-arkadaş) & 63 & 25,8 \\
\hline Medya iletişim araçları & 35 & 14,3 \\
\hline Hepsi & 32 & 13,1 \\
\hline Sağlık personeli+Medya & 21 & 8,6 \\
\hline Sağlık Personeli+Çevre & 11 & 4,5 \\
\hline Sağlık personeli & 9 & 3,7 \\
\hline Toplam & 244 & 100 \\
\hline
\end{tabular}

Evlilik yapacağı kişiyi çeşitli sosyal ve bireysel nedenlerle akrabasından seçenlerin \%87,9'u akraba evliliği yapmaktan memnun, \%12,1'i memnun olmadığını belirtmiş̦tir (Tablo 5).

Tablo 5. Akraba Evliliği Yapan Kadınların Akraba Evliliği Yapmaktan Memnuniyet Durumlarına Göre Dağılımı

\begin{tabular}{|l|c|c|}
\hline \multirow{2}{*}{ Memnuniyet } & \multicolumn{2}{|c|}{ Akraba evliliği yapan kadınlar } \\
\cline { 2 - 3 } & $\mathbf{s}$ & $\mathbf{\%}$ \\
\hline Memnun & 65 & 87,9 \\
\hline Memnun değil & 9 & 12,1 \\
\hline Toplam & 74 & 100 \\
\hline
\end{tabular}

Çalışma grubundaki kadınların akraba evliliğini onaylama durumuna bakıldığında; \%71,3'ü çocuklarının akraba evliliğine onay vermeyeceğini, \%20,3’ü kara- rı çocuğu/çocuklarına bırakacağını ve $\% 8$,4'ü ise buna karşı olmayacağını belirtmiştir. Onay veren ve vermeyen kişilerin akraba evliliğini seçme durumu karşılaştırıldığında, akraba evliliği yapan grubun onay verme oranı anlamlı olarak daha yüksek bulunmuştur (Tablo 6; $\mathrm{p}=0,000$ ).

\section{TARTIŞMA}

Akraba evliliği dünya çapında da oldukça yaygın olarak tercih edilmektedir. Özellikle Afrika ve Orta Asya ülkelerinde yapılan araștırmalar bunun göstergesidir. Akraba evliliğinin en s1k görüldüğü ülkeler olan Suudi Arabistan ve Kuveyt'te halkın yarısı (\%54) akrabasıyla evlidir. Bunu sırasıyla Birleşik Arap Emirlikleri (\%50,5), Ürdün (\%50), Pakistan ve Hindistan (\%3849), İsrail Arap Toplumu (\%44), Suriye (\%33), M1sir (\%28), Lübnan (\%25), Cezayir (\%23) izlemektedir (Hamamy, Jamhavi, Al-Darawsheh ve Ajlouni 2005; Hussain, Bittles ve Sullivan 2001; Hussain 2002; Jaber, Halpern ve Shohat 2000; Sharkia ve ark. 2008; Stoltenberg-Magnus, Lie, Kjersti ve Lorentz 1997). Avrupa'da ise akraba evliliği oranı Doğu ve Akdeniz ülkelerine göre oldukça düşüktür. Fuster ve Colantonia (2003)'nın İspanya'da Hıristiyan kilisesinin arşivlerinden 1888-1976 yıllarındaki akraba evliliğinin gidişatını belirlemek amacıyla yaptığı çalışmada akraba evliliği sıklığında fazla bir değişme görülmemiş ve ortalama oran \%3.6 olarak bulunmuştur. Bu değer ile Avrupa ülkelerindeki en yüksek orana sahip ülkelerden biri olan İspanya olarak bulunurken, araştırmac1lar bunu Bask popülasyonundan (İspanya'nın kuzeyi ve Fransa'nın güney batısındaki özerk bölgede yaşayan halk) kaynaklandığını düşünmektedir. Miguel , Sanchez, Aresti, Pena ve Calderon (2005) Baskların alanlarındaki küçük veya büyük nüfus çalışmalarında

Tablo 6. Kadınların Akraba Evliliği Durumlarına Göre Çocuklarının Akraba Evliliğini Onaylama Durumları Arasındaki İlişkiye Göre Dağılımı

\begin{tabular}{|c|c|c|c|c|c|c|c|c|}
\hline \multirow{2}{*}{ Onay Verme Durumu } & \multicolumn{2}{|c|}{ Akraba evliliği var } & \multicolumn{2}{|c|}{ Akraba evliliği yok } & \multicolumn{2}{|c|}{ Toplam } & Sd & Ki-kare/p değeri \\
\hline & $\mathrm{n}$ & $\%$ & $\mathbf{N}$ & $\%$ & $\mathbf{n}$ & $\%$ & \multirow{4}{*}{2} & \multirow{4}{*}{$\begin{aligned} \mathrm{X}^{2} & =69,917 \\
\mathrm{p} & =0,000\end{aligned}$} \\
\hline Onaylayan & 22 & 29,7 & 4 & 1,7 & 26 & 8,4 & & \\
\hline Onaylamayan & 30 & 40,6 & 191 & 80,9 & 221 & 71,3 & & \\
\hline Diğer & 22 & 29,7 & 41 & 17,4 & 63 & 20,3 & & \\
\hline
\end{tabular}


yakın akraba çiftleşmelerinin oranı genellikle İberian ve Avrupa'nın nüfus standartları ile karşılaştırıldığında aşırı derece de yükssek olduğunu pekiştirmektedirler ve bu farkın coğrafi bölge ve coğrafyanın insanları, sosyoekonomik durum ve dil farklılığından kaynaklanabileceğini savunmaktadırlar (Miguel ve ark. 2005).

Türkiye İstatistik Kurumu (TÜİK) 2006 yılı sonuçlarına göre, akraba evliliği sıklığı \%20,9'dur. Kurumun 2012 de bulduğu oran \%23.3 olarak tesbit edilmiştir (TÜİK 2012). Kutlubay (2007)'ın Malatya'da yaptığı çalışmada, akraba evliliği sıklığ \%28,4; bunların \%74,2'sinin birinci derece kuzen evliliği ve \%12,9'unun uzak akraba evliliği yaptığı bulunmuştur. Ülkemizde çeşitli illere göre de akraba evliliği sıklığı farklılıklar göstermektedir. İstanbul'da \%15,3, Ankara'da \%25,7, Denizli'de \%20,4, Manisa'da \%13, Eskişehir'de \%16,8, Şanl1urfa'da \%49,6, Batman'da \%40, Diyarbakır'da \%31,5, Trabzon'da \%20, Çorum'da \%18,9, Konya'da \%23, Antalya kentsel bölgede \%28 ve kırsal bölgede \%40 olarak bulunmuştur. Akraba evliliğinin bölgeler göre dağılımına bakıldığında, sıklık sırasına göre; Güneydoğu Anadolu Bölgesi'nde \%40,5, Doğu Anadolu Bölgesi'nde \%30,5, Karadeniz Bölgesi'nde \%25, Akdeniz Bölgesi'nde \%23,2, Ege Bölgesi'nde \%17,4 ve Marmara Bölgesi'nde \%10 olarak bulunmuştur (Başaran ve ark. 1988; Karaoğlu, Öztürk ve Pehlivan 2002;Özcan 2008; Tavukçu ve İrgil 2008; TÜíK 2006). Bu oranlar Türkiye'de iller arasında olduğu kadar bölgesel farklılıklarında etkili olduğunu çarpıcı bir şekilde ortaya koymaktadır. Aydındaki akraba evliliği oranı Türkiye'nin batı bölgesindeki illerin sonuçları ile benzeşmektedir. Aydın il merkezinde de bu oranın Türkiye geneline paralel çıkması 3 Sağlık Ocağı bölgesinde yaşayan nüfusun göç alan bölge olması ve akraba evliliğini seçenlerin bu nüfusta yoğunluk kazanmasına ve bu bölgelerin sosyo-demografik özelliklerinin düşük oluşuyla ilgili olabileceği düşünülmektedir.

Aydın il merkezinde kadınların ve erkeklerin eğitim düzeyi arttıkça akraba evliliğini seçme oranı azalmaktadır. Malatya'da 2007 yılında yapılan bir çalışmada da kadınların eğitim durumu arttıkça akraba evliliği yapma sayısı azaldığı fakat eğitim durumu ve akra- ba evliliği arasındaki farkın istatistiksel olarak anlam11 bulunmadığı ve erkeklerin eğitim durumunun da akraba evliliğini seçme durumunda etkili olmadığı sonucuna varılmıştır (Kutlubay 2007). Şenel ve ark. (2009) çalışmasında kadınların eğitim düzeyinin akraba evliliğini etkilemediği ve erkeklerin eğitim düzeyi arttıkça akraba evliliğinin azaldığı sonucuna ulaşılmıştır. Bizim çalışmamızda temel sosyo-demografik ve sosyokültürel değişkenlerden biri olan eğitim düzeyindeki artışın kadının ve erkeğin akraba evliliğine eğilimini azalttığı görülmektedir.

Çalışmayan kadınlarda akraba evliliği daha fazla iken erkeklerin meslek yaşamı akraba evliliği ile karşılaştırıldığında ise istatistiksel olarak anlamlı fark bulunmamıştır. Kutlubay (2007)'ın çalışmasında kadınların ve erkeklerin meslek yaşamları ile akraba evliliği arasında anlamlı bir ilişki bulunmamıştır. Fakat Tavukçu ve İrgil (2008) yaptıkları çalışmada kadınların çalışma durumları ve akraba evliliği arasındaki ilişkiyi anlam11 bulmuşlardır ve sonuç bu çalışma bulgularını desteklemektedir.

Kadınların en uzun süre yaşadıkları yerleşim yeri incelendiğinde akraba evliliğini tercih eden kadınların $\% 43$,2'sinin, akraba evliliğini tercih etmeyen kadınların ise \%23,3'ünün köyde yaşadıkları sonucu bulunmuştur. Rao ve İnbaraj (1977) kırsal kesimde akraba evliliği oranını $\% 47$ ve kentte ise $\% 29$ olarak bulmuştur. Zencir (2005) akraba evliliği sıklığının kırsal bölgede doğmuş ve on iki yaşına kadar kırsal bölgede yaşamış olan kadınlarda daha yüksek olduğunu; yaşanılan yer açısından değerlendirildiğinde kentsel bölgeden kırsal bölgeye doğru gidildikçe artma eğiliminde olduğunu tespit etmiştir. Hayatlarının büyük çoğunluğunu kırsal kesimde geçiren kadınların akraba evliliğine eğilimlerinin daha fazla olduğu göze çarpmaktadır. Kırsal alanlarda geleneklerin daha yaygın uygulanması ve alışkanlıkların devam etmesi ve coğrafi konum bunda etkili olabilir. Kadınların yaşadıkları aile tipine göre akraba evliliği yapma durumları arasındaki fark anlamlı bulunmuştur. Tabak (2008)'ın yaptığı çalışmada da geniş ailelerde akraba evliliğinin daha çok görülmesi ile benzer bulgular elde edilmiştir. 
$\mathrm{Bu}$ çalışmadaki katılımcıların ekonomik durumları, bir sosyal güvenceye sahip olma durumları ve akraba evliliği karşılaştırıldığında istatistiksel olarak anlaml1 fark bulunmamıştır. Ancak ekonomik durumu kötü olan ailelerde akraba evliliğinin daha sık olduğu belirten kaynaklar vardır (Altuntek 2001; Tunçbilek ve Koç 1994).

Çalışma grubunda 18 yaş ve altında evlenen akraba evliliği yapan kadınlar \%55,4 iken, akraba evliliği yapmayan kadınlarda \%34,7'dir ve aradaki fark istatistiksel olarak anlamlıdır. Benzer sonuçlara Karaoğlu ve ark. (2002)'nın Çorum ilinde, Zencir (2005) Denizli ilinde ve Tavukçu ve İrgil (2008) Bursa ilinde yaptıkları çalışmalarda da rastlanmaktadır. Çalışma sonuçlarına göre, evlilik yaşı artıkça akraba evliliği seçme eğilimi azalmaktadır.

Bu çalışmada akraba evliliğini tercih eden 74 kadından sadece 10'unun $(\% 13,5)$ genetik danışma aldığı belirlenmiştir. Kahramanmaraş'ta Dönbak, Demirhan ve Çelik (2005)' in yaptıkları çalışmada akraba evliliği yapanlar arasında genetik danışmanlık hizmetleri hakkında bilgisi olanların oranı \%20,8 olarak bulunmuştur. Değirmenci, Köstek, Başkır ve Sarıçam (2006)'ın yaptığı bir başka çalışmada ise katılımcılar içerisinde genetik danışmanlığın tanımını doğru yapanların oranının sadece $\% 16,9$ olduğu bildirilmiştir.

Akraba evliliği yapan kadınlara akraba evliliği seçme nedenleri sorulduğunda, ilk sırada buna ailelerin karar verdiğini ve görücü usulü ile olduğu, ikinci sırada birbirlerini sevdikleri ve üçüncü sırada geleneksel nedenler zorunluluk şeklinde yanıt verildiği görülmektedir. Ülkemizde yapılan çalışmalarda benzer nedenler belirtilmektedir. (Ayan, Beder-Şen, Ünal ve Yurtkuran 2001; Kayahan, Şimşek, Ersin, Gözükara ve Kurçer 2003; Tavukçu ve İrgil 2008; Tekbaş ve ark. 2005). İsrail-Arap toplumunda yapılan bir çalışmada akraba evliliğine neden olarak; sıklıkla sülale dayanışması, kişilerin birbirine uygunluğu, aile mülkünün korunması, ana-baba otoritesi ve kadınların sosyal olarak korunması gösterilmiştir. Pakistan'daki bir çalışmada ise akraba evliğini seçme nedenleri; planlanmış evlilik ve aileden biriyle evlenmenin daha sağlıklı olduğu ve geleneksel uygulamalar gösterilmiştir (Hussain ve ark. 2001; Sharkia ve ark. 2008). Akraba evliliklerinin aşiret yapısını koruyan topluluklarda, aşiret kimliğini sürdürmede etkili olduğu ve soy-içi evliliğin bu maksatla teşvik edildiği sonucuna varılmıştır (Altuntek 2001).

Akraba evliliği yapan kadınların yapmayanlara göre akraba evliliğinin, doğacak çocukların sağlığ 1 için sakıncalı olmadığı görüşü anlamlı olarak daha fazladır. Çalışma grubundaki akraba evliliği yapan kadınların büyük çoğunluğunun çocuklarında herhangi bir sağlık sorunu olmadığ 1 için böyle düşündükleri söylenebilir. Ülkemizdeki akraba evliliği ile yapılmış çalışmaların sonuçları ile bu çalışma sonuçları benzemektedir (Ayan ve ark. 2001; Değirmenci ve ark. 2006; Mayda ve ark. 2010; Tabak 2008; Tavukçu ve İrgil 2008).

Evlilik yaptığı kişiyi akrabasından seçen kadınların bu evlilikten \%87,9'u memnun olduğunu ifade etmiştir. Ayan, Beder-Şen, Yurtkuran ve Ünal (2002)'ın çalışmasında da akraba evliliği yapanların \%80'inin bu durumdan memnun olduklarını ifade ettikleri ve memnuniyet gerekçelerini, eşlerini sevdikleri,eşlerin tanıdık olması ve yabancı biriyle evliliğin daha kötü olabileceği şeklinde ifade etmişlerdir. Ayan ve ark. (2002)'na göre bu ifadelerin geleneksel bir evlilik şekli olan akraba evliliğinin temelinde yatan yapı taşları olduğu düşünülmektedir.

Kadınların çok azı çocuklarının akraba evliliği yapmasını onayladığını, önemli bir çoğunluğu onaylamadığın ifade etmişlerdir. Bu soruya daha çok onay veren kişilerin akraba evliliği yapan grup olması dikkat çekmektedir. Tabak (2008) çalışmasında kadınların çocuklarının akraba evliliği yapma durumuna onay verip vermeyeceklerini sorduğunda $\% 69,5$ 'inin onaylamayacağ $1, \% 26,9$ 'unun onaylayacağ 1 ve \%3,6'sının net bir fikri olmadığı sonucuna varmıştır.

\section{SONUÇ VE ÖNERILER}

$\mathrm{Bu}$ çalışmanın sonucunda kadının eğitim durumunun, çalışma durumunun, yaşadığı yerin, aile tipinin ve ilk 
evlilik yaşının akraba evliliğine olan eğilimini etkilediği görülmüştür. Akraba evliliklerini azaltmak için kadının eğitiminin sağlanması, ekonomik özgürlüklerinin sağlanması ve ilk evlenme yaşlarının ertelenmesi önerilebilir. Hemşirelerin akraba evliliği yapmış olan kadınları genetik danışmanlık hakkında bilgilendirmeleri ve genetik danışmaya yönlendirip izlemlerinin sürdürülmesi, akraba evliliğinin riskleri ve zararları konusunda halkın medya iletişim araçları ile aydınlatılması diğer önerilebilecek konular arasında yer alabilir. Bu çalışmada kadınların akraba evliliği ile ilgili bilgileri en az oranla sağlık personelinden edindiği görülmüştür. Bu doğrultuda sağl1k personelinin konuyla ilgili duyarlılı̆̆ını arttıran hizmet içi programların yapılması önerilebilinir.

\section{KAYNAKLAR}

Altuntek, N. S. (2001). Türkiye üzerinde yapılmış evlilik ve akrabalık araştırmalarının bir değerlendirmesi. Hacettepe Üniversitesi Edebiyat Fakültesi Dergisi, 18(2): 17-28.

Ayan, D., Beder-Şen, R., Ünal, G., Yurtkuran, S. (2001). Ankara'da akraba evliliği. Aile ve Toplum Dergisi, 4(1): 7-26.

Ayan, D., Beder-Şen, R., Yurtkuran, S., Ünal, G. (2002). Akraba evliliğinin kültür birikiminde ve toplum hayatındaki bazı görünümleri: Dil, din ve tıp. Aile ve Toplum Dergisi, 2(5): 77-84.

Başaran, N. ve ark. (1988). Consanguineous marriages in the Turkish population. Clinical Genetics, 34: 339-341.

Değirmenci, F., Köstek, O., Başkır, B., Sarıçam, M. H. (2006). Toplumda genetik hastalıklar ve genetik danışmanlık ile ilgili bilgi düzeylerinin saptanması. Marmara Üniversitesi Tip Fakültesi Dergisi, 19(3): 34 .

Dönbak, L., Demirhan, İ., Çelik, M. (2005). Genetik danışmanlık hizmetleri: Kahramanmaraş’ta tanımlayıcı bir çalışma. Sürekli Eğitim Tlp Dergisi (STED), 14(9): 192-194.

Fuster, V., Colantonia, S. E. (2003). Inbreeding coefficients and degree of consanguineous marriages in Spain: A review. American Journal of Human Biology, 15: 709-716.

Genç, Z., Erdemir, A. D. (1997). Genetik Sorunlar ve Tıbbi Etik (Genetik Danışma). 1. basım, Nobel Tıp Kitabevi, İstanbul.

Hamamy, H., Jamhavi, L., Al-Darawsheh, J., Ajlouni, K. (2005). Consanguineous marriages in Jordon: Why is rate changing with time? Clinical Genetics, 67: 511-516.
Hussain, R. (2002). Ley perceptions of genetic risk attributable to inbreeding in Pakistan. American Journal of Human Biology, 14: 267-274.

Hussain, R., Bittles, A. H., Sullivan, S. (2001). Consanguinity and early mortality in the Muslim populations of India and Pakistan. American Journal of Human Biology, 13(6): 777-787.

Jaber, L., Halpern, G. J., Shohat, T. (2000). Trends in the frequencies of consanguineous marriages in the Israeli Arap community. Clinical Genetics, 58(2): 106-110.

Kayahan, M., Şimşek, Z., Ersin, F., Gözükara, F., Kurçer, M. A. (2003). Şanlıurfa Tılfındır Sağlık Ocağı Bölgesi'nde akraba evliliği prevalansı ve 5 yaş altı ölümlere etkisi. Cumhuriyet Üniversitesi Hemşirelik Yüksek Okulu Dergisi, 7(1): 1-5.

Karaoğlu, L., Öztürk, C., Pehlivan, E. (2002). Çorum İli bir sağlık ocağı bölgesinde yaşayan evli kadınlarda doğurganlık ve etkileyen faktörler. İn̈̈n̈̈ Üniversitesi Tıp Fakültesi Dergisi, 9(1): 33-40.

Kutlubay, A. (2007). Malatya ilinde akraba evliliği sıklığ ve tıbbi sonuçları. Yüksek Lisans Tezi, İnönü Üniversitesi Sağlık Bilimleri Enstitüsü, Malatya.

Mayda ve ark. (2010). Düzce ili Yığılca ilçe merkezinde akraba evliliği sıklığı ve etkileyen faktörler. Düzce Tlp Dergisi, 12(2): 36-41.

Miguel, A., Sanchez, A., Aresti, U., Pena, J. A., Calderon, R. (2005). Inbreeding levels and consanguinity structure in the Basque Province of Guipuzcoa (1862-1980). American Journal of Physical Anthropology, 127: 240-252.

Özcan, M. (2008). Akraba evlilikleri ve genetik danışmanlık. Sürekli Tıp Eğitim Dergisi, 17(4): 62-66.

Özvarış, Ş. B., Koçoğlu, O. G, Akın, A. (2002). Türkiye'de Akraba Evlilikleri. 8. Ulusal Halk Sağlığı Kongresi Kitabl, Dicle Üniversitesi Basımevi, Diyarbakır, 575-578.

Özvarış, Ş. B. (2001). Evlilik öncesi danışmanlık. Beksaç, M. S., Demir, N., Koç, A. (Eds.). Maternal-Fetal Tip ve Perinatoloji/ Obstetrik: Maternal-Fetal Tip ve Perinatoloji. Medikal Network, İstanbul, 124-127.

Rao, P. S. S., İnbaraj, S. G. (1977). Inbreeding effects on human reproduction in Tamil Nadu of South India. Annual Human Genetics, 41: 87-98.

Saygıl1, S. (1998). Akraba evliliği. Yeni Dünya Dergisi, 5(1): 1-5.

Sharkia, R. ve ark. (2008). The changing pattern of consanguinity in selected region of the Israeli Arap Community. American Journal of Human Biology, 20: 70-77.

Stoltenberg, C., Magnus, P., Lie, R. T., Kjersti, D. A., Lorentz, M. İ. (1997). Birth defects and parental consanguinity in Norway. American Journal of Epidemiyology, 145(5): 439-448. 
Şenel, E., Şahin, C., Süslü, İ., Güntürk, H. (2009). Lise öğrencilerinin akraba evliliği konusundaki bilgi düzeyi ve eğilimleri araştırması. Türk Bilim Araştırma Vakfi (TÜBAV) Bilim Dergisi, 2(3): 317-326.

Tabak, A. (2008). Endokrinoloji ve metabolizma polikliniğimizden takipli hastalarda akraba evliliği sıklığı ve akraba evliliğini etkileyen faktörler. Uzmanlık Tezi, T.C. Sağlık Bakanlığı İstanbul Bakırköy Kadın Doğum ve Çocuk Hastalıkları Eğitim ve Araştırma Hastanesi, İstanbul.

Tavukçu, N., İrgil, E. (2008). Bursa Nilüfer Halk Sağlığı Eğitim ve Araştırma Bölgesi'nde yaşayan kadınlarda akraba evlilikleri. TSK Koruyucu Hekimlik Bülteni, 7(2): 107-112.

Tekbaş, Ö. F., Oğur, R., Uçar, M. (2005). Genç erişkin erkekler arasında akraba evliliği sıklığının nedenlerinin araştırılması. TSK Koruyucu Hekimlik Bülteni, 4(3): 120-128.
Tunçbilek, E., Koç, İ. (1994). Consanguineous marriage in Turkey and its impact on fertility and mortality. Annual Human Genetics, 58: 321-332.

T.C. Başbakanlık Türkiye İstatistik Kurumu (TÜİK) (2006). Aile Yapısı Araştırması, Ankara.

T.C. Başbakanlık Türkiye İstatistik Kurumu (TÜİK) (2012). Aile Yapısı Araştırması, Ankara.

Uskun, E. (2001). Akraba evlilikleri. Sürekli Tıp Eğitim Dergisi, 10(2): 54-56.

Zencir, S. (2005). Denizli ilinde akraba evliliği sıklığı ve tıbbi sonuçları. Yüksek Lisans Tezi, Pamukkale Üniversitesi Sağlık Bilimleri Enstitüsü, Denizli. 